\title{
Pemberdayaan Masyarakat Pendamping Lansia Dalam Pemanfaatan dan Pembuatan Sabun Herbal di Masa Pandemi Covid-19
}

\author{
Luluk Anisyah, Sugiyanto \\ STIKes Panti Waluya Malang \\ Email : luluk.anisyah1977@gmail.com
}

\begin{abstract}
Abstrak
Meningkatnya angka harapan hidup dapat menyebabkan populasi usia lebih dari 60 tahun akan meningkat pada tahun 2050, sehingga hal ini akan menyebabkan masalah kesehatan salah satunya adalah kelembaban dan pruritus pada kulit. Tujuan dalam pengabdian masyarakat ini untuk meningkatkan kemampuan, pengetahuan dalam membuat sabun herbal cair, cara penggunaan, serta manfaat. Metode pelaksanaan yang digunakan dalam pengabdian masyarakat kepada grup pendamping lansia (SMAN 01 Sumber Pucung Malang) secara daring dengan menggunakan zoom meliputi 3 kegiatan antara lain: Tahap persiapan: melakukan pendekatan, persiapan bahan dan alat yang digunakan untuk pembuatan sabun herbal cair; Tahap pelaksanaan yang dilaksanakan pada tanggal 8-9 februari 2021 dengan memberikan edukasi kesehatan dan pelatihan terkait manfaat, cara penggunaan, dan penyebaran video pembuatan sabun herbal cair; Tahap evaluasi dilakukan terhadap apresiasi grup. Hasil dari dilakukannya pengabdian adalah dapat berjalan baik dan lancar sesuai dengan yang telah dijadwalkan, hal tersebut sesuai dengan jumlah prosentase dengan nilai rata-rata $66 \%$ setuju dan $34 \%$ sangat setuju dalam peningkatan ketrampilan pada pendamping lansia; sedangkan jumlah prosentase yang menunjukan keberhasilan dalam pemberian edukasi untuk meningkatkan pengetahuan adalah dengan nilai rata-rata $72 \%$ setuju dan $28 \%$ sangat setuju dari google form. Kesimpulan bahwa tujuan untuk meningkatkan pengetahuan terkait pemanfaatan daging kakao dan daging, serta kulit lidah buaya yang digunakan sebagai sabun herbal cair kepada para pendamping lansia dapat tercapai.
\end{abstract}

Kata Kunci : Sabun herbal cair, Antiseptik, Pelembab

\begin{abstract}
The increasing life expectancy can cause the population aged over 60 years to increase by 2050, so this will cause health problems, one of which is moisture and pruritus on the skin. The purpose of this community service is to improve abilities, knowledge in making liquid herbal soap, how to use it, and benefits. The implementation method used in community service to the elderly companion group (SMAN 01 Sumber Pucung Malang) online using zoom includes 3 activities, including: Preparation stage: approaching, preparing materials and tools used for making liquid herbal soap; The implementation stage which will be held on February 8-9, 2021 by providing health education and training related to the benefits, how to use, and distribution of videos of making liquid herbal soap; The evaluation stage is carried out on group appreciation. The results of the service are that it can run well and smoothly according to what has been scheduled, this is in accordance with the number of percentages with an average value of $66 \%$ agree and $34 \%$ strongly agree in improving the skills of elderly companions; while the percentage that shows success in providing education to increase knowledge is with an average value of $72 \%$ agree and $28 \%$ strongly agree from google form. The conclusion is that the goal of increasing knowledge related to the use of cocoa meat and meat, as well as aloe vera skin used as liquid herbal soap for elderly companions
\end{abstract} can be achieved.

Keywords : Liquid herbal soap, Antiseptic, Moisturizer

http://ejournal.urindo.ac.id/index.php/PAMAS 


\section{PENDAHULUAN}

\section{ANALISIS SITUASI}

\section{Kesehatan kulit pada lansia}

Menurut Badan Kesehatan Dunia (WHO), bahwa Covid-19 dapat menginfeksi semua orang tanpa mengenal kelompok usia, akan tetapi WHO juga menyebutkan bahwa kelompok yang paling rentan terpapar oleh virus corona adalah lansia. Beberapa ahli sepakat bahwa usia menjadi faktor dominan yang menyebabkan lansia menjadi rentan. Umumnya orang tua memiliki kulit kering. Keadaan fisiologi kulit kering akan dapat menimbulkan rasa gatal karena sensitif terhadap rangsangan mekanis, kimiawi, dan lain-lain. Salah satu penyebab terjadinya kulit kering yang dapat menyebabkan rasa gatal adalah karena berkurangnya kelembaban di kulit (Seftiani, 2020). Terjadinya kulit kering yang banyak dialami oleh para lansia dapat menyebabkan terjadinya rasa gatal, selain karena adanya faktor kelembaban yang berkurang dengan semakin bertambahnya usia, maka pada kulit kering pada lansia juga bisa karena akibat proses penuaan kulit, sehingga kulit menjadi lebih peka terhadap rangsangan ringan yang menyebabkan rasa gatal. Untuk mengatasi kulit kering yang dapat menimbulkan gatal-gatal, umumnya memang bisa digunakan pelembab, dimana pelembab bisa digunakan 2 kali sehari setelah mandi. "Namun pada kulit kering dapat digunakan lebih sering sesuai dengan kebutuhan,". Jika dengan adanya penggunaan pelembab dari luar saja tidak cukup, maka langkah pertama untuk mengurangi terjadinya kulit semakin kering yaitu melalui pemilihan sabun mandi, mandi tidak terlalu lama dan sering, serta tidak menggunakan air yang terlalu hangat. Kemudian memilih pelembab yang lebih kuat atau berminyak, serta para lansia dan orang-orang memiliki kulit kering agar minum cukup air putih dan menghindari suhu ruangan yang terlalu dingin.

\section{Limbah pasca panen pada kakao}

Limbah pertanian merupakan bahan yang terbuang di sektor pertanian. Limbah dianggap suatu bahan yang tidak penting dan tidak bernilai ekonomi. Padahal jika dikaji dan dikelola, limbah pertanian dapat diolah menjadi beberapa produk baru yang bernilai ekonomi tinggi. Untuk mengatasi masalah ini, maka salah satu cara yang dapat dilaksanakan adalah melaksanakan pengolahan limbah pertanian misalnya tanaman coklat. Limbah tersebut meliputi limpah pra-panen dan limbah paska panen. Tujuan dari pengolahan limbah sendiri adalah untuk menjaga kstabilan ekologi pertanian coklat dan dapat digunakan sebagai bahan pembuat masker wajah sehingga bisa meningkatkan pendapatan secara umum Tanaman coklat banyak menghasilkan limbah, antara lain adalah kulit buah, dan daging buah (pulp) (Hasanah et al., 2015). Saat ini kulit buah kakao hanya limbah pada perkebunan kakao rakyat yang selalu berlimpah dan belum dikelola dengan baik. Kulit 
buah tersebut menimbulkan masalah pencemaran lingkungan. Pemanfaatan kulit buah kakao sebagai pakan dan pupuk masih kurang efektif karena berdasarkan komponen kimianya, kulit buah kakao mengandung $18 \%$ pektin, $2 \%$ tanin, $0,01 \%$, katekin dan $1,04 \%$ antosianin. Untuk saat ini pengolahan kulit kakao hanyalah sebatas sebagai pakan dan pupuk (Partayasa et al., 2017). Berdasarkan uraian pemanfaatan daging buah kakao yang kita dapat dari daerah malang selatan, maka dilakukan pembuatan sabun herbal dari kombinasi daging buah kakao dan kulit serta daging buah Lidah buaya melalui program pengabdian kepada masyarakat secara daring, sehingga bisa meningkatkan pengetahuan tentang manfaat sabun herbal dan cara penggunaannya.

\section{Pemberian ketrampilan pembuatan sabun herbal}

Seiring bertambahnya usia, maka sering terjadi adanya kulit kering dan kelembaban yang berkurang pada para lansia, sehingga dapat menyebabkan terjadinya rasa gatal, maka pada kulit kering pada lansia juga bisa karena akibat proses penuaan kulit, sehingga kulit menjadi lebih peka terhadap rangsangan ringan yang menyebabkan rasa gatal. Untuk mengatasi kulit kering yang dapat menimbulkan gatal-gatal, umumnya memang bisa digunakan pelembab. Jika dengan adanya penggunaan pelembab dari luar saja tidak cukup, maka langkah pertama untuk mengurangi terjadinya kulit semakin kering yaitu melalui pemilihan sabun mandi. Keunggulan pada sabun herbal yang diformulasikan ini adalah terdiri dari kombinasi tanaman kakao dan kulit serta daging buah Lidah buaya, madu, milk, serta oleum olivae. Keunikan dari sabun herbal ini adalah berbentuk sabun herbal cair sehingga dalam pemakaiannya bisa langsung dipakai sesuai dengan kebutuhan. Kegiatan Pengabdian kepada masyarakat ini bertujuan untuk mengangkat manfaat bahan alami kombinasi dari daging buah tanaman kakao dan kulit serta daging buah lidah buaya sebagai bahan dasar sabun herbal yang aman untuk jenis kulit pada lansia.

\section{RUMUSAN MASALAH}

Berdasarkan latar belakang di atas dapat dirumuskan masalah penelitian sebagai berikut:

1. Pemanfaatan limbah dari daging buah kakao dan kulit,serta daging buah lidah buaya yang masih jarang dimanfaatkan sebagai antioksidan dalam bentuk sabun herbal cair

2. Masih minimnya produk sabun herbal cair yang khusus digunakan untuk kulit lansia

3. Masih kurangnya pengetahuan masyarakat pendamping lansia tentang pemanfaatan daging kakao dan daging, serta kulit lidah buaya yang digunakan sebagai sabun herbal cair 
Jurnal Pelayanan dan Pengabdian Masyarakat (PAMAS)

\section{METODE}

\section{Tahap Persiapan}

Melakukan pendekatan pada grup pendamping lansia, dan menyiapkan bahan dan alat yang digunakan untuk pembuatan sabun herbal cair.

\section{Tahap pelaksanaan}

Memberikan edukasi kesehatan dan pelatihan terkait manfaat, cara penggunaan sabun herbal cair, dan penyebaran video pembuatan sediaan tersebut ke grup pendamping lansia.

Tahap evaluasi dilakukan terhadap apresiasi grup pendamping lansia dengan menghitung prosentase sangat setuju dan setuju dari google form pendamping lansia.

\section{Hasil Kegiatan Pengabdian Masyarakat}

Tabel Kegiatan dan Hasil Kegiatan PkM di Kabupaten Malang

\begin{tabular}{|c|c|c|c|}
\hline Waktu & Kegiatan & Tujuan & Hasil \\
\hline 15 Desember 2021 & $\begin{array}{l}\text { Persiapan Bahan Baku } \\
\text { (Pengeringan Daging } \\
\text { buah Kakao dan Kulit } \\
\text { buah Lidah buaya) }\end{array}$ & $\begin{array}{l}\text { Mendapatkan sediaan } \\
\text { simplisia yang kering }\end{array}$ & $\begin{array}{l}\text { Serbuk simplisia yang } \\
\text { sudah kering dan siap } \\
\text { digunakan }\end{array}$ \\
\hline 24 Desember 2020 & $\begin{array}{l}\text { Pembelian bahan } \\
\text { tambahan (Oleum } \\
\text { olivae, Propilenglikol, } \\
\text { Asam Stearat, TEA, } \\
\text { Propil paraben, Metil } \\
\text { paraben, Madu) }\end{array}$ & $\begin{array}{l}\text { Sebagai bahan } \\
\text { tambahan/basis dalam } \\
\text { pembuatan masker } \\
\text { wajah antiaging }\end{array}$ & $\begin{array}{lr}\text { Didapatkan } & \text { bahan } \\
\text { tambahan } & \text { dari } \\
\text { Distributor } & \end{array}$ \\
\hline 19 Januari 2021 & $\begin{array}{l}\text { 1.Pembuatan sediaan } \\
\text { Sabun Herbal } \\
\text { 2.Pengambilan video } \\
\text { pada saat pembuatan } \\
\text { sediaan Sabun Herbal }\end{array}$ & $\begin{array}{lr}\text { 1.Didapatkan } & \text { sediaan } \\
\text { Sabun Herbal } & \\
\text { 2.Didapatkan } & \text { video } \\
\text { pembuatan } & \text { sediaan } \\
\text { Sabun Herbal } & \\
\end{array}$ & $\begin{array}{l}\text { 1.Sediaan Sabun } \\
\text { Herbal } \\
\text { 2. Video pembuatan } \\
\text { sediaan }\end{array}$ \\
\hline 20 Januari 2021 & Edit video & $\begin{array}{l}\text { Didapatkan hasil video } \\
\text { yang baik }\end{array}$ & $\begin{array}{l}\text { Video pembuatan } \\
\text { sediaan }\end{array}$ \\
\hline 21 Januari 2021 & $\begin{array}{l}\text { Pengumpulan video ke } \\
\text { LPPM }\end{array}$ & $\begin{array}{l}\text { Untuk mendapatkan } \\
\text { link edukasi }\end{array}$ & Link edukasi \\
\hline 08 Februari 2021 & $\begin{array}{l}\text { Share link edukasi ke } \\
\text { pendamping lansia }\end{array}$ & $\begin{array}{l}\text { Untuk memberikan } \\
\text { edukasi } \\
\text { pendamping } \quad \text { pada } \\
\text { tentang pembuatan } \\
\text { Sabun Herbal yang } \\
\text { disertai } \\
\text { edukasi }\end{array}$ & $\begin{array}{l}\text { Tanya jawab melalui } \\
\text { grup pendamping } \\
\text { lansia }\end{array}$ \\
\hline 09 Februari 2021 & $\begin{array}{l}\text { Evaluasi } \\
\text { pengisian } \\
\text { google form }\end{array}$ & $\begin{array}{l}\text { 1.Mengukur tingkat } \\
\text { ksesuaian sediaan } \\
\text { yang dibuat dengan } \\
\text { kesesuaian partisipan } \\
2 . \quad \text { Mengukur } \\
\text { keberhasilan proses } \\
\text { pemberian edukasi }\end{array}$ & $\begin{array}{l}\text { 1. Jumlah prosentase } \\
\text { yang bagus } \\
\text { 2. Pendamping lansia } \\
\text { mendapat edukasi } \\
\text { yang lengkap dan } \\
\text { tepat }\end{array}$ \\
\hline
\end{tabular}




\section{PEMBAHASAN}

Hasil kegiatan pengabdian kepada masyarakat dengan topik Pemberdayaan Masyarakat Pendamping Lansia Dalam Pemanfaatan Daging Buah Kakao dan Daging Buah Lidah Buaya Sebagai Bahan Pembuatan Sabun Herbal di Masa Pandemi Covid 19 dapat berjalan dengan baik dan lancar sesuai dengan yang telah dijadwalkan oleh tim pengabdian masyarakat STIKes Panti Waluya Malang. Sabun herbal ini cocok digunakan untuk lansia, serta bahan sabun herbal ini merupakan kombinasi dari tanaman herbal yang mempunyai khasiat sebagai antioksidan yang dapat mencegah radikal bebas serta tanaman herbal yang mempunyai khasiat dapat menjaga kelembaban pada kulit, terutama kulit lansia. Keberhasilan ini terlaksana atas kerjasama antara tim pengabdian masyarakat STIKes Panti Waluya serta para partisipasi pendamping lansia. Peran aktif peserta pendamping lansia dalam kegiatan PkM ini dapat disimpulkan baik. hal tersebut sesuai dengan jumlah prosentase dengan nilai rata-rata $66 \%$ sangat setuju dan $34 \%$ setuju dari google form dalam peningkatan ketrampilan pada pendamping lansia; sedangkan jumlah prosentase yang menunjukan keberhasilan dalam pemberian edukasi untuk meningkatkan pengetahuan adalah dengan nilai rata-rata $72 \%$ setuju dan $28 \%$ sangat setuju.

\section{SIMPULAN}

Pelaksanaan kegiatan pengabdian masyarakat yang dilakukan oleh tim STIKes Panti Waluya Malang terhadap partisipasi pendamping lansia dapat berjalan dengan baik, lancar, dan sukses. Hal ini disebabkan adanya kerjasama yang baik antara pihak STIKes Panti Waluya dengan para partisipasi pendamping lansia pada saat pelaksanaan kegiatan tersebut yang telah dilaksanakan pada saat pembuatan sediaan serta pada saat pemberian materi edukasi dengan menggunakan video melalui media online dengan baik dan lancar serta peran partisipan pendamping lansia yang aktif mengikuti edukasi tersebut. Atas dasar inilah proses kegiatan pengabdian masyarakat di partisipasi pendamping lansia dapat disimpulkan dapat tercapai.

\section{UCAPAN TERIMA KASIH}

Ucapan terima kasih kami sampaikan kepada Yayasan Pendidikan Misericordia, Bapak Ketua STIKes Panti Waluya Malang (Wibowo,S.Kep.,Ns.,M.Biomed), Grup pendamping lansia (siswa-siswi SMAN 01 Sumber Pucung Malang), dan Rekan-rekan di STIKes Panti Waluya Malang. 


\section{DAFTAR PUSTAKA}

1. Gusviputri, A., Meliana, N., Aylianamawati, \& Indraswati, N. (2013). Pembuatan Sabun Dengan Lidah Buaya (Aloe vera) Sebagai Antiseptik Alami. Widya Teknik, 12(1), 11-21.

2. Hasanah, A. N., Fk, S. A., Saptarini, N. M., Ramdhani, D., Ariyanti, A., Ng, H., Suherman, S. E., Low, K., \& Ling, K. (2015). IBM Pembuatan Minuman Kesehatan Cuka Coklat Dari Limbah Pulp Biji Coklat. Farmaka, 13(4), 10-15.

3. Partayasa, I. N., Kadir, S., \& Rahim, A. (2017). Kapasitas Antioksidan Suplemen Pada Berbagai Berat Ekstrak Bubuk Pod Husk Kakao. E-J.Agrotekbis, 5(1), 9-17.

4. Rahmatiyah. (2012). Penggunaan Butil Hidroksi Toluen Untuk Menghambat Ketengikan Minyak Kelapa Hasil Olahan Petani. Jurnal Matematika Sains Dan Teknologi, 13(2), 88-93. http://jurnal.ut.ac.id/JMST/article/view/451

5. Raisa, A., Hutagaol, R. P., \& Srikandi. (2016). Optimasi Penambahan Madu Sebagai Zat Anti Bakteri Staphylococcus aureus, Pada Produk Sabun Mandi Cair. Jurnal Sains Natural Universitas Nusa Bangsa, 6(2), 52-63.

6. Sari, N. R., \& Setyowati, E. (2014). Pengaruh Masker Jagung dan Minyak Zaitun terhadap Perawatan Kulit Wajah. Journal of Beauty and Beauty Health Education, 3(1).

7. Seftiani, S. (2020). Lansia dalam Situasi Pandemi COVID-19. Pusat Penelitian Kependudukan LIPI, 1-4. https://kependudukan.lipi.go.id/id/berita/53-mencatatcovid19/847-lansia-dalam$\underline{\text { situasi-pandemi-covid-19 }}$

8. Sujono Dian; Kusuma, Hendra, S. I. (2020). Pendampingan Proses Produksi Sabun Natural Mayangsari Di Kelompok Bumdes Desa Pesanggrahan Kota Batu. PengabdianMu: Jurnal Ilmiah Pengabdian Kepada Masyarakat, 5(3), 294-298. http://journal.umpalangkaraya.ac.id/index.php/pengabdianmu/article/view/1327

9. Vikasari, S. N., Hermanto, F., Simatupang, E., Sutjiatmo, A. B., Sutarna, T. H., Puspadewi, R., Rachmawan, L., \& Haq, F. A. (2020). Efek Iritasi Sabun Mandi Batang Mengandung Susu Produk Usaha Kecil Menengah di Kota Cimahi. Jurnal Kefarmasian Indonesia, 10(2), 95-101. https://doi.org/10.22435/jki.v10i2.2592 